UDK 32.019 .51

004.738.5:316.472.4

316.774

Originalni naučni rad

Ljubomir A. MILJKOVIĆ*

Business and Law Faculty, Belgrade

Olja M. ARSENIJEVIĆ **

Faculty of Business Studies and Law, Belgrade

Dragana M. TRNAVAC ${ }^{* * *}$

Business and Law Faculty, Belgrade

\title{
POLITICAL COMMUNICATION WITH POPULATION THROUGH SOCIAL MEDIA
}

\begin{abstract}
In this paper, the authors deal with social media as tools of political interaction with the public of the political party. The aim of the paper is to present the essence of social media as one of the most important social, marketing and cultural phenomena of today. Another goal of the paper is to examine the impact of social media in the politics on civic engagement and public opinion. The paper analyses social media, with a special focus on Facebook and Twitter, and the most important social media researches in political interaction with citizens are presented.
\end{abstract}

Key words: social media, political communication, PR strategy, political campaign, Facebook, Twitter.

\section{INTRODUCTION}

Social media are one of the most important social, marketing and cultural phenomena of today. Social media are a group of applications based on the Internet that allow individuals or groups to create, collaborate, and share content with each other.

Social media have emerged from the development of the Internet. We could say that the emergence of Web 2.0 was a tremendous step forward in relation to the previous version of the Internet - Web 1.0, making it unique, in a true sense, interactive virtual market. In this way, Web 2.0 has contributed to the multiplicity of social media capabilities being used to their maximum.

* Ph. D. ljubomir.miljkovic@ppr.edu.rs

** Full-time professor, olja.arsenijevic@fpsp.edu.rs

*** Assistant professor, dragana.trnavac@ppf.edu.rs 
There are very few people who are immune to social media today and do not use them. Social media are a topic that cannot be avoided. Social media allow ordinary people to follow the content they are interested in, track people and events, share information and knowledge about different areas and domains of life, learn and advance in knowledge and skills, publish their views and opinions, and give a critical overview of the numerous content that they are interested in.

There is no area in which social media cannot be applied. They are also present in the sphere of politics. The importance of social media is growing in politics. They are increasingly used as a means of exchanging opinions, attitudes and criticism regarding ruling political options. The public is increasingly actively involved in politics, either through active monitoring of content of a political nature or through direct communication with public political actors. In Serbia, political parties and politicians have realized this great importance of social media and use them to promote their ideas or exchange opinions and attitudes with the public.

In this paper we are going to discuss the impact of social media in politics, how social media are used in political interaction, and how they affect citizens and public opinion.

Recognizing the capacity of social media in terms of their openness towards the audience and initiating and encouraging the audience to respond to specific content being placed on them, giving comments and attitudes, evaluating their views and sharing information with the interested parties, the new role and functions of social media have been quickly understood and it is now used for the purpose of marketing, politics, PR and other areas of social life.

Research in developed countries shows that social networks are increasingly used in marketing and politics. Thus, in the United States, the former President Barack Obama's team used the power of social media to win votes in the preelection campaign. But before that, social media were widely used for political purposes. Such examples are, in addition to Barack Obama's campaign for the US president, 2008: the 2011 demonstration in Spain 2011, the Arab Spring 2011, 'Occupy Wall Street' in New York 2011, which later expanded to other cities, etc.

Based on a comprehensive survey conducted in 2016 by Singapore's marketing company "We Are Social”, which encompassed 232 countries, including countries in the region as well as Serbia, the results showed that nearly $50 \%$ of the world's population, or 3.42 billion people used the Internet daily, and mobile devices are actively used by 3.79 billion people, or $51 \%$ of the world's population. Furthermore, social networks' profiles have one third of people, or over 2.3 billion, while almost two billion social network users access their profiles by mobile phones $-27 \%$ of the world's population. 


\section{THE ROLE OF SOCIAL MEDIA IN POLITICAL INTERACTION WITH THE POPULATION}

\subsection{THE NOTION AND DEFINITION OF SOCIAL MEDIA}

Social media are a technological, cultural, social and marketing phenomenon of today. They emerged with the development of the Internet and the differentiation of various web services and a variety of content on the Internet.

What are social media?

There are many different definitions of social media in literature. We will list here one of the most important definitions given by Thackeray, Neiger and Keller: "Social media are a group of applications based on the Internet that allow individuals to create, collaborate and share content with each other" (Thackeray et al. 2015). According to Kaplan and Haenlein, social networks are applications that allow users to connect and create profiles with personal information, invite friends and colleagues to access those profiles and send emails and instant messages to each other (Kaplan-Haenlein 2010).

According to S. Neti, the essence of social media is reflected in networking. This networking refers to the sharing, exchange and critical consideration of information and knowledge between different entities. She says: "Any website that allows users to share their content, opinions, and views and encourage interaction and community building can be classified as social media" (Neti 2011).

Social media has become one of the most powerful platforms available to us for marketing, communication and building social relationships.

The enormous growth of the Internet has made a number of contents accessible to ordinary citizens, and the development of social media has enabled the population to track a lot of information and knowledge on the Internet, and actively participate in creating individual or group content, and to exchange opinions, ideas, insights, etc.

The explosion of social media is a phenomenon that must be taken into consideration. Hence this phenomenon could not go unnoticed by the ruling social structures. The influence of social media on human behaviour and activities, as well as public opinion, has been recognized by political subjects, which opened the door for the massive use of social media for political purposes in the last decade of the 21 st century.

Of all these social media, social networks have the highest value from the point of view of marketing and political communication. Among the social networks particularly important are the following: Facebook, Twitter, Linkedin, Instagram, Flickr, Pinterest, etc. 


\subsection{ANALYSIS OF SOCIAL MEDIA WITH A SPECIAL FOCUS ON FACEBOOK AND TWITTER}

Today there are many different social media that have been developed for certain specific application domains. The vast diversity of available social media gives a wide range of uses. What is common to all social media and what links them all is the possibility of interactive communication of content on the Internet. People today become users of several different types of social media at the same time because they use their different options.

Social media have radically changed the way of communication. The question arises as to what is new that the social media have brought in the field of communication. According to S. Miladinovic, eight innovations brought by social media in communication can be singled out (Miladinović 2015). These are:

The first innovation: Social media allow anonymity of those who send messages. It is done in the way that those who write messages, comments, posts etc. do this by using nicknames, pseudonyms or fake names, which allows them to secretly comment on various sensitive issues, but also to avoid the responsibility for their public announcements. The result of this is that now anonymous people or outsiders have an impact on public opinion.

The second innovation: Social media provide a wealth of diverse information so that users are no longer dependent on just one source of information, but can switch from one medium to another. It is also possible to easily and quickly combine, compare and select various types of content offered through social media

The third novelty is omnipresence, which means that there is no more privacy in the sense that it has been previously understood, that is, there is more and more mixing of private and public life. Users can now do their own personal promotion, present themselves through social media, have their followers, comment on various content, exhibit their photos, their works, etc. Because of this, the media space becomes cluttered with information about marginal personalities because everyone wants to break through, expose or impose on the public. As a consequence of such a relationship, the boundaries between genuinely significant and marginal entities in various areas of social life are being erased.

The fourth innovation is speed, which implies a high speed of spreading various news and information. Social media make it possible for anyone now to be notified and be able to report to the public about an event, person, etc. Also, the speed of information dissemination leads to the fact that we are overwhelmed with a large number of unverified or contradictory information about the same event. Speed prevents precise and accurate checking of information that is shared.

The fifth novelty refers to the many roles that social media users download in their relations. Thus, the user at the same time is the author and editor and commentator and critic, but also the object of various news or information. 
The sixth innovation is the transition from objective to subjective reporting. Media independence is slowly disappearing. There is a lack of creative dialogue, criticism and openness for a different opinion. Instead of an argumented exchange of thought, it insists on subjectivity, personal experience, and fierce reverence for certain privileged individuals, groups or supporters of one's opinion. Social media give the opportunity to comment, but are lacking moderators or administrators who should play the role of controlling published content. If it has some sort of selection, this selection is mostly subjective, unargumental and very often ends in hate speech, pronouncing different insults, calling for a lynch, and so on. All this is complemented by the practice of the so-called bots. Bots are paid commentators who are tasked to represent the interests and goals of certain centres of social power and they write ordered or typed comments or template texts that grossly undermine the principle of truth and create a false picture with which certain ideas and attitudes dominate society.

The seventh novelty creates the possibility of combining different types of information in an extremely flexible way. Therefore, social media are no longer just an image, nor text, nor audio or video content, but all that taken together.

The eighth novelty refers to the absence of traditional forms of regulation. On the one hand, it is difficult to limit the content of social media as it affects privacy, and on the other hand excessive censorship causes too much harm because it hinders free exchange of content. It is a strange phenomenon that news once they enter the media begin to live their own lives, and therefore every possibility of controlling its truthfulness is very difficult. It can be noticed that social media significantly influenced the flow and dynamics of many important events - cultural, political, and economic, etc.

All these novelties contribute to the understanding of social media as an entirely new social phenomenon that is experiencing great popularity among all layers of the population. Their popularity stems from the ability to provide us with the experience of permanent communication and accessibility, as well as the possibility of active participation in various discussions, free creation of views, comments and critical analyses.

Herewith we shall discuss some of the most popular and most important social media used by citizens. Social media can be divided into the following groups:

- forums;

- the social network;

- blogs;

- content sharing sites;

- virtual worlds;

- Social purchasing sites. 
The biggest and most developed social network is Facebook. This network, according to the latest statistics from June 30,2017, today has nearly 2 billion users in the world, which is $26.3 \%$ of the world's total population. Facebook also recorded the highest growth: in 2017 compared to 2010, the number of users of this social network rose by $282.3 \%$ (http://www.internetworldstats.com/ facebook.htm).

Facebook provides a wide variety of features to its users around the world. Users, both individuals and organizations, have their Facebook profile and they update it regularly. Facebook is based on complete real-time interactivity. Users can communicate with each other, exchange different content, upload texts, images, videos or music videos, comment other posts, chat, participate in discussions, follow other members or sites of organizations, join various forums, groups, etc.

The advantages of using Facebook are reflected in the user's easy reference to other sites, clear visibility of the links, and communication independently of space and time. One of the main risks in using Facebook is the visibility of negative comments, which are often censored.

Twitter is a social medium that has proven to be the best to promote various contents in a fast and efficient way. After Facebook, Twitter has the largest audience. It offers excellent options for tracking and commenting. The statuses that are written here may consist of text messages, links, images or videos and are called tweets. Tweets are quickly shared among users (retweets). The biggest advantage of Twitter is the ability to instantly share your tweet - retweet - among users. This feature gives Twitter an advantage over Facebook. Also, tweets are public, so each post is spreading rapidly through the network. Among the risks of using Twitter is the possibility of occurrence of errors, which is the result of ease and speed of use (https://www.wired.com/2016/05/twitter-onboardingtips-for-new-users/).

\subsection{METHODS OF POLITICAL COMMUNICATION WITH THE POPULATION THROUGH USAGE OF SOCIAL MEDIA}

As previously stated, social media was widely used as an effective way of political communication between political subjects and citizens. Although the original purpose of social media was focused on private use, in terms of private interaction, the development of the Internet in Web 2.0 had given many opportunities for usage, extending the scope of using social media from the private to the public sphere.

Politicians have numerous opportunities in using social media for the purpose of political communication with the population. Political parties can open 
their site on one of the social media - it is advisable to do it on Facebook and Twitter. Politicians as individuals can make their own personal profile. It is necessary to be continuously active on a page or profile. This includes numerous activities: forms:

a) Regular posting of content of a political nature that can take various

- news or information about significant political events;

- comment or critical reviews of significant political events;

- uploading of video or audio recordings;

- sharing posts of other politicians or public figures, etc.

b) updating communication with friends (in the Facebook environment) or followers (in the Twitter environment):

- adding friends / followers;

- sharing posts between friends / companions;

- updating and expanding the base of friends / followers, etc.

c) interactive communication with friends / followers:

- notification of significant events;

- referring to certain significant events;

- seeking opinion or attitude by friends / companions;

- survey of friends / companions and others.

d) addressing the public.

Politicians use social media as an effective means of promoting their own views and opinions. In this way, they quickly and efficiently connect with their followers and thus can broaden their base of supporters and monitor and analyse reactions, comments and reviews of their activities.

The development of social media has led to the public being better acquainted with key economic and political issues of public interest. Social media changed the political environment and initiated broad democratization of information much faster and more successful than the mainstream media (DuttaBhat 2016).

When we talk about the influence of social media on political interaction with the population, we can mention the so-called logic of social media and the logic of networked media. Both approaches refer to "understanding specific mechanisms, practices and norms that create dynamics between users, platforms, mass media and institutions. Media logic can be defined as "a set of principles or common sense rationality cultivated in and through media institutions that penetrate into each public domain and dominate its organizational structure" (Altheide-Snow 1979). 
Three important issues concerning the use of social media for the purpose of political communication can be highlighted. These are the following ones:

1. How do citizens connect and interact with political actors through social media?

2. What opportunities are used in interaction between citizens and political actors?

3. How do different categories of citizens (in demographic terms) affect their political activity through the use of social media?

In his study on the impact of social media on politics, Kathurwar has drawn five basic ways of using social media in politics (Kathurwar 2017).

1. Direct interaction (for voters and politicians). Social media allows politicians to interact with voters at no cost. Also, there is a greater possibility for voters to interact more easily with political entities. A good example of this is "live streaming".

2. Publication of free campaigns. Social media platforms allow political parties to advertise their campaigns at no cost. Thus, advertisements for political campaigns are released free of charge on social media in addition to paid standard ads that are broadcast on radio or television.

3. Growth of campaign popularity. Social media ensure that political campaigns are "viral", which means they are written and spoken about in public. In this way, they contribute to increasing the popularity of these campaigns.

4. Customization of the demographics of the audience based on messages. Social media are sensitive to the demographic dimensions of the population, so in political campaigns messages can be adapted to a certain age, gender, race, ethnicity, and so on.

5. Rumours, false news and controversy. The availability of the campaign to a wider circle of people brings about weaknesses, which are reflected in the fact that, apart from the true image of a politician, there are a lot of false news, disinformation, controversy and speculation.

\section{REVIEW OF THE PREVIOUS RESEARCH OF SOCIAL MEDIA IN POLITICAL INTERACTION WITH THE POPULATION}

Awareness of the importance of social media to achieve political communication and the interaction of political subjects with citizens rose during the campaign of former US President Barack Obama from 2008 to 2012. The Obama campaign was characterized by the so-called "social computing". American citizens 
were given the opportunity to voice important political issues, even if they were not engaged in politics. The presentation of political candidates on social networks was encouraging for citizens to become part of political life.

Kaplan and Heinlein suggested guidelines for more effective use of social networks during both Obama's presidential candidacies: a) a careful choice or development of one's own application where the candidate will be most active, since online activity is key to success and $b$ ) the choice of a communication service followed by a target group of users (Pierov 2017).

The key component of Obama's political campaign was openness to communicating with voters. The most important element of Obama's campaign was the "BarackObama.com" page. A user-oriented version of this site was called myBarackObama.com or shortened MyBO. It was a kind of special social network created only for the purpose of the campaign and enabled users to connect and politically activate themselves.

Based on a comprehensive survey conducted in 2017 by the Singaporebased marketing company "We Are Social", (https://wearesocial.com/sg/ blog/2017/01/digital-in-2017-global-overview) that encompassed over 230 countries, including countries in the region and Serbia, the results showed that almost $50 \%$ of the world's population, or 3.77 billion people used the Internet daily, has 2.8 billion global users of social media or $37 \%$ of the world population, 4, 92 billion global mobile users, which was $66 \%$ of the share and 2.56 billion global mobile social media users, or $34 \%$ of the world's population. Then, social networks have one third of people, or over 2.3 billion, while almost two billion social network users access their profiles by mobile phones $-27 \%$ of the world's population.

A research conducted in 2016 by the marketing agency Pew Research Centre (Pew Research Centre, http://www.pewinternet.org/2016/10/25/politicalcontent-on-social-media/), shows the importance and impact of social media on political communication. Based on this research, it can be generally concluded that social media users monitor and comment on political events. Nearly one-third of respondents stated that they frequently (9\%) or occasionally (23\%) comment, discuss or respond to social media on social issues. It is noticeable that younger people more than older people rely on social media as a source of campaign news, but older ones are more likely to hold their point of view when discussing or commenting on political issues.

When it comes to the most popular social media - Facebook and Twitter, there are clear differences in the structure of friends/followers. The vast majority of Facebook users $-66 \%$ say they personally know their friends, about $30 \%$ say they are a mixture of known and unknown, while only $3 \%$ of users say that most friends are people they do not know personally. Unlike Facebook, Twitter users declare that they mostly turn to public figures and unknown users: only $15 \%$ 
of Twitter users declare that they mainly follow people who they know personally, and $48 \%$ say they mostly follow people who they do not know personally.

Despite this diversity of Facebook and Twitter users in terms of followers, users of both social media have said they are following and discussing politics at a similar level. Thus, 25\% of users of Facebook and 24\% of Twitter users state that much of what they see in their communications is related to politics, while $6 \%$ of Facebook users and $8 \%$ of Twitter users have declared that much of what they place on their accounts is related to politics.

It is clear that there is a certain polarization among users of Facebook or Twitter, in that the users are divided into the majority of those who do not care too much about politics and a little bit of those who are significantly interested in political communication. Most of these politically active users believe that social media can play a useful role in enabling people to become familiar with political issues and engage in communication with political parties or candidates they find important. Thus, one in five social media users declare that they have changed their attitudes about a political candidate or a social topic under the influence of materials found on the appropriate site.

Regarding the scale of political content on social networks, about $20 \%$ of users said they wanted to see a multitude of posts on social media policy, but about $37 \%$ said they were "tired" with the political content of posts and discussions.

The vast majority of social media users think that people in social media are expressing themselves differently than in reality, or that their attitudes on social media are important to the views expressed in the public. As many as $84 \%$ of social media users agree with that view.

When faced with a generally negative tone of political conversation, $83 \%$ of social media users reported that they usually ignore such a post, while a minority of users (15\%) declare that they are actively engaged in the discussion, even though they do not agree with the interlocutor.

Despite often negative views on political interactions seen on social media, people frequently change their views on political issues after confronting them with opposing views. Thus, $20 \%$ of users stated that they changed their views on certain political or social issues because they saw something different on social media, while $17 \%$ said that they changed their mind about a particular political candidate. They specifically mentioned that they exchanged views on presidential candidates Hilary Clinton and Donald Tramp.

It has been established that presidential candidates increasingly use social media to reach the public directly. About $25 \%$ of social media users reported that they followed candidates or other political figures. About $65 \%$ of users stated that they mainly followed people with whom they share the same political attitudes, $31 \%$ of users said they followed a mix of people with different political attitudes, while only $3 \%$ of users said that mainly followed people with differing attitudes from theirs. 
Among social media users who are more engaged in political communications, $19 \%$ said they frequently commented, question or discussed policy issues or countries with other users. These users also see a higher level of negativity in the tone of political discussion in social media, but they also express greater optimism about the possibility of social media to facilitate or enable political dialogue and action.

In the research of the use of the Internet as a means of political communication in Croatia by D. Mustić, I. Balabanić, M. Mustapić, it was established that political parties in Croatia "recognize the Internet as a promotional site, but not as a place where a user can become an equal participant in communication process" (Mustić-Balabanić i dr. 2012).

\section{CONCLUSION}

It could be said that political parties did not distinguish between different types of audience, but they perceived the public as a homogeneous entity that had the same information or communication needs. Almost all parties are poorly using all the possibilities of interaction communication between social media users and political parties, so they have largely disabled the options on their site that allow commenting, participating in fora or chatting by users. Thus, the political parties' websites mostly serve as "bulletin boards" for representing party politicians and information on the party's activities. In addition, links to other Internet sites and networking almost do not exist, and parties do not generally participate in popular social media - Facebook, Twitter, YouTube.

Communication as the means and goal of the strategy should not be a means to achieve a political goal, but an integral part of politics. It should be a means and goal of developing and explaining the strategy. "Strategic communication as a service: In the course of functional differentiation, politics is increasingly turning to service providers in the field of communication. However, services in this field are strategic only if they go beyond the capability of the campaign to respond to the needs of a specific region, and are able to transfer the framework of interpretation of the leading ideas in which the strategic course is properly integrated" (Sarcinelli 2011).

\section{REFERENCES}

Altheide-Snow 1979: David L. Althiede - Robert P. Snow. Media logic. Beverly Hills, California, Sage.

Dutta-Bhat 2016: Nirankush Dutta - Anil Bhat. Use of Social Media for Political Engagement: A Literature Review, ResearchGate, Conference Paper. December 2016. <https:// www. researchgate.net/publication/312468953>.

Internet World Stats, Facebook users in the world. <http://www.internetworldstats.com/facebook.htm>. 
Kaplan-Haenlein 2010: Andreas M. Kaplan - Michael Haenlein. "Users of the world, unite! The challenges and opportunities of Social Media”. Business Horizons, 53(1), 59-680.

Kathurwar 2017: Kathurwar Shishir. Power Of Online And Social Media: Changing The Political Landscape. <https://reportgarden.com/2017/09/18/social-media-political-landscape/>.

Miladinović 2015: Slobodan Miladinović. "Rastući značaj socijalnih medija u dinamičnom društvu". Tradicija, modernizacija i nacionalni identitet u Srbiji i na Balkanu u procesu evropskih integracija. <https://izdanja.filfak.ni.ac.rs/zbornici/2015/download/1384_ 5b117f08f5f73539e639bcdf13ea78e0>.

Mustić-Balabanić i dr. 2012: Daria Mustić, Ivan Balabanić, Marko Mustapić. "Korištenje interneta kao sredstva političke komunikacije u Hrvatskoj”. Media, Culture and public relations, 3.

Neti 2011: Sisira Neti. „Social media and its role in marketing“. International Journal of Enterprise Computing and Business Systems, Vol. 1, Issue 2. <http://www.ijecbs.com>.

Pierov 2017: Tihana Pierov. Rastući utjecaj društvenih mreža u predizbornim kamanjama. Završni rad. Filozofski fakultet, odsjek za informacijske i komunikacijske znanosti. Sveučilište u Zagrebu.

Sarcinelli 2011: Ulrich Sarcinelli. „Strategija i politička komunikacija“. U: Menadžment političke komunikacije - osnove i koncepti. Beograd: Fondacija Konrad Adenauer.

Thackeray-Neiger et al. 2015: Rosemary Thackeray, Brad L. Neiger, Heidi Keller. „Integrating social media and social marketing: A four-step process“. Health Promotion Practice, vol. 13 , issue $2,165-168$.

The political environment on social media, Pew Research Center. <http://www.pewinternet. org/2016/10/25/political-content-on-social-media/>.

How to use Twitter? Critical tips for new users. <https://www.wired.com/2016/05/twitter-onboarding-tips-for-new-users/>.

We are social. $<$ https://wearesocial.com/sg/blog/2017/01/digital-in-2017-global-overview >. 


\author{
Ljubomir A. MILJKOVIĆ \\ Olja M. ARSENIJEVIĆ \\ Dragana M. TRNAVAC
}

\title{
POLITIČKA KOMUNIKACIJA SA GRAĐANIMA PUTEM SOCIJALNIH MEDIJA
}

\begin{abstract}
REZIME
Može se reći da političke stranke ne prave razliku između različitih tipova publike, već javnost doživljavaju kao homogenu celinu koja ima iste informacijske ili komunikacione potrebe. Gotovo sve stranke slabo koriste sve mogućnosti interakcijske komunikacije između korisnika socijalnih medija i političkih stranaka, tako da su one u većini onemogućile opcije na svom sajtu koje dozvoljavaju komentarisanje, učestvovanje na forumima ili ćaskanje od strane korisnika. Tako same internet stranice političkih stranaka uglavnom služe kao „oglasne ploče“ za predstavljanje stranačkih političara i informacija iz aktivnosti stranke. Osim toga, povezanost sa drugim internetskim lokacijama i umreženost skoro i da ne postoji, a stranke uglavnom ne učestvuju u popularnim socijalnim medijima - Fejsbuk, Tviter, Jutjub...

Komunikacija kao sredstvo i cilj strategije ne bi smela da bude sredstvo za postizanje političkog cilja, nego sastavni deo politike. Ona bi trebalo da bude sredstvo i cilj razvoja i objašnjavanja strategije. „Strateška komunikacija kao usluga: U toku funkcionalne diferencijacije politika se takođe sve više okreće pružaocima usluga u oblasti komunikacije. Međutim, usluge u toj oblasti dobijaju strateški karakter samo onda ako prevazilaze okvir sposobnosti kampanje da odgovori potrebama određenog regiona, i u stanju su da prenesu i okvir tumačenja vodećih ideja u kojima je na pravi način integrisan strateški kurs" (Sarcinelli 2011).

Ključne reči: socijalni mediji, politička komunikacija, PR strategija, politička kampanja, Fejsbuk, Tviter.
\end{abstract}

Rad je predat 8. novembra 2018. godine, a nakon mišljenja recenzenata, odlukom odgovornog urednika „Baštine“ odobren za štampu. 